\title{
Memaknai Penyelamatan Zipora terhadap Rencana Pembunuhan Musa oleh Tuhan
}

\author{
Firman Panjaitan \\ Sekolah Tinggi Teologi Tawangmangu, Jawa Tengah \\ panjaitan.firman@gmail.com
}

\begin{abstract}
In the Bible it is often found a difficult part to understand, especially in this paper about the plan of the Lord who wanted to kill Moses. Even if you look deeper, Moses is a person sent by the LORD to free the nation of Israel from occupation in Egypt. This section needs to be examined more deeply, so that it can be searched for what is the basis of this action of the Lord, and at the same time what theological meanings are contained in this section, which are also relevant to present life. Through word study research efforts, it can be found that the plan of the Lord to kill Moses was not a playful plan, but it was a truly serious plan. But all these plans could be failed because Zipporah, the wife of Moses, succeeded in making atonement with the LORD through the foreskin of Moses 'son who was affixed to Moses' pubic. This indicates that the Lord's plan occurred because Moses was negligent in keeping his holiness, which is to circumcise his child. Holiness is the most important thing in carrying out all forms of service and call of God. If this holiness was ignored, then it could be that the Lord's plan to send someone turned into the anger of the LORD against the one sent.
\end{abstract}

Keywords: holiness; Lord; Moses; Zipporah

\begin{abstract}
Abstrak: Dalam Alkitab seringkali dijumpai bagian yang sulit untuk dipahami. Terkait dengan tulisan ini, bagian yang sangat sulit itu adalah tentang rencana TUHAN yang hendak membunuh Musa. Padahal kalau dilihat lebih dalam lagi, Musa adalah orang yang diutus oleh TUHAN untuk membebaskan bangsa Israel dari kerja paksa di Mesir. Bagian ini perlu untuk diteliti lebih dalam lagi, agar dapat dicari apa yang menjadi dasar dari tindakan TUHAN ini, dan sekaligus ditarik makna teologi apa yang terkandung dalam bagian ini, yang juga relevan bagi kehidupan sekarang. Melalui studi kata, maka dapat dijumpai bahwa rencana TUHAN membunuh Musa bukanlah rencana yang main-main, tetapi merupakan rencana yang memang sungguh-sungguh. Namun semua rencana itu dapat digagalkan karena ada Zipora, istri Musa, yang berhasil mengadakan upaya 'pendamaian' dengan TUHAN melalui kulit khatan anak Musa yang ditempelkan ke 'kemaluan' Musa. Ini menandakan bahwa rencana TUHAN itu terjadi karena Musa telah lalai dalam menjaga kekudusan dirinya, yaitu menyunatkan anaknya. Kekudusan merupakan hal terpenting dalam menjalankan segala bentuk pelayanan dan panggilan TUHAN. Apabila kekudusan ini diabaikan, maka bisa saja rencana TUHAN mengutus seseorang berubah menjadi kemarahan TUHAN terhadap yang diutus.
\end{abstract}

Kata Kunci: kekudusan; Musa; Tuhan; Zipora

\begin{tabular}{llll}
\hline Article History : & Received: 04-02-2019 & Revised: 05-03-2019 Accepted: 29-12-2019 \\
\hline
\end{tabular}




\section{Pendahuluan}

TUHAN umumnya digambarkan sebagai sosok yang penuh kuasa dan tidak pernah mengingkari janji-Nya kepada manusia, juga sebagai 'orang yang setia dan konsisten pada setiap perkataan dan janji'. Gambaran umum ini sudah sangat terpateri di dalam benak setiap orang beragama (beriman), sehingga jika didapatkan sebuah pendapat yang menyimpang dari statement di atas, maka pendapat tersebut langsung dimasukkan ke dalam golongan pendapat yang berbau bidat/bid'ah dan sekaligus ini merupakan indikator bahwa yang berpendapat seperti itu adalah orang yang memiliki kadar iman yang rendah. Bagi penganut paham tentang TUHAN yang selalu konsisten di dalam kata dan janji-Nya, setiap pandangan yang bertentangan dengan hal tersebut dipandang sebagai upaya untuk mendeskriditkan TUHAN dan harus ditetapkan sebagai pandangan yang sesat. Namun apakah benar demikian adanya, bahwa pandangan yang mencoba melihat tindakan TUHAN dari sudut pandang yang berbeda dapat dikatakan sebagai pandangan yang sesat dan sekaligus menunjukkan kadar keimanan yang rendah?

Pandangan yang terungkap di atas sering menggejala dalam kehidupan beragama di Indonesia. Dalam banyak pengalaman rohani, setiap pendapat yang menyangkut pribadi TUHAN selau dikaitkan dengan masalah janji keselamatan dan konsistensi TUHAN dalam menjaga janji-Nya kepada manusia. Ada kecenderungan yang kuat dalam diri setiap manusia untuk menciptakan 'tokoh TUHAN' seperti apa yang dipikirkan dan dipahami oleh manusia. Dengan demikian pribadi dan karya TUHAN selalu ditempatkan di dalam kerangka pemenuhan keinginan dan kepentingan manusia yang selalu haus terhadap pemenuhan janji TUHAN kepada mereka, khususnya yang sifatnya baik-baik saja. Apabila, suatu saat, ditemukan bahwa janji TUHAN itu tidak sesuai dengan keinginan dan kepentingan, manusia cenderung mengatakan bahwa bukan TUHAN yang tidak memenuhi janji-Nya kepada manusia, melainkan dipandang sebagai cobaan dan ujian bagi ketabahan dan keimanan seseorang dalam menanti penggenapan janji TUHAN dalam hidup mereka. Timbul pertanyaan, apakah hal ini tidak menunjukkan bahwa kebebasan dan kemahakuasaan TUHAN telah dipenjarakan dalam pola pikir dan kepentingan manusia? Juga, apakah hal ini tidak menunjukkan bahwa keberadaan TUHAN ditentukan oleh sikap dan kepentingan manusia, sehingga TUHAN tidak memiliki 'ruang gerak' yang cukup untuk ikut terlibat dalam kehidupan manusia.

Selain itu ada hal yang ingin disoroti dan dikritisi, tentang situasi kehidupan manusia yang seringkali didasarkan atas pandangan yang bias gender, atau ketidakadilan gender. Dalam kenyataan hidup, posisi/kedudukan seorang perempuan seringkali ditempatkan dalam situasi yang serba tidak menguntungkan. Mereka seringkali ditempatkan dalam posisi 'warna negara' kelas dua dan kurang mendapatkan penghargaan seperti layaknya seorang laki-laki. Hal ini dapat dilihat dalam system pembagian kerja dalam keluarga, yang seringkali didasarkan atas system pembagian kerja secara seksual, dimana domain perempuat terletak di dapur dan di tempat-tempat 
yang berisfat melayani laki-laki, sedangkan laki-laki dipandang sebagai pencari nafkah utama dalam keluarga. Kalau pun perempuan bekerja, hasil pekerjaan perempuan 'hanya' dipandang sebagai hasil kerja yang sifatnya untuk menambah kebutuhan keluarga. Laki-laki, yang dipandang sebagai kepala keluarga (decision maker), tidak perlu terlalu mengurusi urusan rumah, karena semua itu (termasuk mendampingi anak) adalah tugas kewajiban seorang perempuan. ${ }^{1}$

\section{Metode Penelitian}

Penelitian ini merupakan penelitian kualitatif literatur dengan menggunakan metode analisis teks, yang mengarahkan perhatian yang lebih khusus pada penggunaan kritik historis. Melalui metode kritik historis ini, setiap teks akan diteliti dan dianalisis, dengan tujuan agar makna teks yang ada dalam perikop terpilih dapat ditemukan. Adapun langkah yang dilakukan dalam menggunakan metode historis kritis adalah:

Pertama, dalam upaya menafsir dan menggali makna yang terdapat dalam Keluaran 4:24-26, maka akan lebih mengkonsentrasikan pada metode kritik teks (text criticism), yaitu sebuah metode untuk mengidentifikasi varian-varian tekstual dalam suatu naskah/manuskrip atau dokumen cetak. ${ }^{2}$ Selain itu juga akan digunakan metode penafsiran Alkitab yang bermuara pada kritik bentuk form criticism atau formgeschichte), yang mengonsentrasikan pada bagian-bagian teks yang lebih luas, terkhusus apa yang menjadi latar belakang dekat dan jauh dari teks terpilih. Secara keseluruhan metode ini menaruh perhatian lebih pada unit atau bagian terkecil yang lebih singkat dari suatu teks atau tulisan. Kritik bentuk ini meneliti proses penyampaian berita (yang ditulis berupa teks), dimulai dari bentuk pewartaan secara lisan (dari mulut ke mulut) hingga bentuk tertulis yang dimiliki sekarang ini. ${ }^{3}$

Kedua, setelah selesai menggunakan metode tafsir di atas, maka dicari kesesuaian konteks penulisan masa lalu dengan teks yang ada di dalam Alkitab. Dengan demikian melalui upaya penafsiran tersebut, penulis dapat menemukan makna terdalam dari teks Keluaran 4:24-26, khususnya yang berbicara tentang upaya Zipora untuk menyelamatkan Musa, suaminya, dari rencana pembunuhan yang telah dirancangkan oleh Allah.

Ketiga, langkah terakhir yang akan digunakan dalam metode ini adalah mencari dan menemukan apa yang menjadi implikasi kisah Keluaran 4:24-26 dengan masa kini. Hal ini perlu, karena dengan mengimplikasikan kisah Alkitab ke masa sekarang berarti berusaha menghidupkan kembali teks-teks Alkitab ke dalam kehidupan nyata. Sehingga

\footnotetext{
${ }^{1}$ Carwoto, "Mengungkap dan Mengeliminasi Kekerasan Terhadap Istri” dalam Rifka Annisa, Menggugat Harmoni. (Yogyakarta: Rifka Annisa Women's Crisis Center, 2000), h. 85-91, bdk. dengan Loekman Soetrisno, Kemiskinan, Perempuan, dan Pemberdayaan. (Yogyakarta: Kanisius, 1997), h. 94-95 dan lih. juga Rifka Annisa, Di Balik Tirai Tabu (Yogyakarta: Rifka Annisa Women's Crisis Center, 2000), h.vii-viii

2 Bart D. Ehrman, Misquoting Jesus: The Story Behind Who Changed the Bible and Why. (Harper Collins, 2005), 46.

3 Robinson Radjagukguk, “Apa itu Penelitian Bentuk”, dalam Forum Biblika, No.8, 1998.
} 
Alkitab tidak menjadi teks yang mati, tetapi tetap menjadi teks yang senantiasa up-todate, sepanjang masa.

\section{Permasalahan Di Sekitar Redaktur}

Kritik terhadap narasi teks Keluaran 4:24-26 adalah mengenai peran Zipora yang sangat dominan. Hal ini, agaknya, kurang lazim di kalangan tulisan-tulisan kitab Perjanjian Lama yang begitu didominasi oleh pandangan patriarkhal. Agaknya ada keistimewaan dalam masalah redaktur di sini, sehingga redaktur memberikan tempat istimewa bagi hadirnya seorang perempuan dalam kehidupan seorang utusan TUHAN. Hal ini terlebih dahulu hendak penulis kupas, agar keistimewaan kehadiran seorang perempuan dalam kisah ini dapat terjawab.

A. Kuenen dan J. Wellhausen, pada akhir abad XIX ${ }^{4}$ mengemukakan pendapatnya mengenai teori sumber bagi kelima kitab awal dalam Perjanjian Lama, yang dikenal dengan sebutan Pentateukh. Mereka berpendapat bahwa Pentateukh memiliki empat sumber dalam penceritaannya, yaitu sumber Yahwist (Y), sumber Elohist (E), sumber Deuteronomist (D), dan sumber Priest (P). Dan jika mau ditelusuri dengan teliti, berdasarkan pembagian-pembagian yang ada di antara keempat sumber tersebut, maka kisah dalam Keluaran 4: 24-26 dapat dimasukkan ke dalam kisah-kisah yang ditulis oleh sumber atau redaktur $\mathrm{Y}^{5}$, yang secara khusus dipandang sebagai penulis sejarah Israel dari kisah penciptaan sampai dengan kisah keluarnya bangsa Israel dari penjajahan Mesir dan perkembangannya setelah mereka berada di tanah Perjanjian, Kanaan.

Dalam tulisan-tulisannya, sumber $\mathrm{Y}$ dipanang memiliki ciri khas utama, yaitu mengenai penggambaran sosok TUHAN secara anthropomorfistis (TUHAN digambarkan dalam bentuk seorang manusia)6, sehingga melalui penggambaran ini TUHAN dipandang bukan sebagai TUHAN yang transenden (jauh dan tak terjangkau) saja melainkan sekaligus immanen (dekat dan dapat dijangkau). Dan jika kembali menyoroti kisah dalam Keluaran 4: 24-26 di atas, nyatalah bahwa penggambaran mengenai TUHAN yang dihadirkan merupakan gambaran TUHAN yang anthropomorf. Inilah salah satu alasan yang diberikan oleh Harold Bloom untuk mengatakan mengapa kisah ini digolongkan ke dalam kisah yang ditulis oleh redaktur Y.7

Namun penelitian di atas belum menjawab pertanyaan mengenai peranan seorang perempuan yang begitu dominan dalam kisah Keluaran 4: 24-26. Oleh sebab itu perlu diperhatikan pendapat Bloom yang memberikan penjelasan menarik, di mana ia mengatakan bahwa sesungguhnya redaktur sumber $\mathrm{Y}$ ini adalah seorang perempuan,

\footnotetext{
${ }^{4}$ J. Bloomendal, Pengantar Kepada Perjanjian Lama (Jakarta: BPK Gunung Mulia, 1983), 17-22

${ }^{5}$ Referensi yang penulis pakai disini berdasarkan atas terjemahan yang dilakukan dalam David Rosenberg dan Harold Bloom, The Book ofJ (New York: Faber \& Faber, Grove Weidenfeld, 1990), 55-139

${ }^{6}$ J. Bloomendal, Pengantar Kepada Perjanjian Lama, 18 dan hal ini juga disetujui oleh David Rosenberg dan Harold Bloom, The Book of J, 10

${ }^{7}$ Lihat dalam bagian Introduction dan After Commentary yang ditulis oleh Harold Bloom dalam David Rosenberg dan Harold Bloom, The Book of J, 10, 265-266.
} 
dan di dalam tulisan selanjutnya Bloom pun menempatkan kisah mengenai Zipora sebagai alas an untuk membuktikan bahwa redaktur dari sumber $\mathrm{Y}$ ini adalah perempuan. ${ }^{8}$

Apa yang diungkapkan oleh Bloom memiliki kebenaran, karena bila setiap tulisan (produk tulisan) yang dibuat oleh sumber Y diperhatikan maka akan didapatkan kesan yang begitu condong pada keberpihakan dan pembelaan terhadap kaum perempuan. Di bawah ini penulis akan memberikan beberapa contoh dari hasil tulisan dari redaktur atau sumber $\mathrm{Y}$ yang begitu peduli dan berpihak terhadap keberadaan kaum perempuan: ${ }^{9}$

a. Dalam kisah penciptaan (Kej. 2), redaktur Y dengan berani menggambarkan mengenai kesetaraan perempuan dan laki-laki (lihat ungkapan mengenai perempuan diciptakan dari tulang rusuk laki-laki, perempaun adalah penolong yang sepadan dengan laki-laki dan perempuan adalah tulang dari tulang dan daging dari daging seorang laki-laki).

b. Dalam kisah mengenai kejatuhan manusia ke dalam dosa (Kej. 3), di satu sisi digambarkan bahwa sebelum perempuan memakan buah pengetahuan itu, terlebih dahulu ia berdialog dengan ular; di sisi lainsosok-laki-laki digambarkan tidak memiliki inisiatif sama kelai dan hanya menurut saja apa yang diperintahkan oleh perempuan.

c. Dalam kisah Abram dan Sarai (Kej. 12: 10-20) digambarkan bagaimana peran Sarai yang bersedia mengurbankan dirinya demi keselamatan Abram, dan Abram sendiri digambarkan sebagai seorang laki-laki pengecut yang tega menjual istrinya hanya demi keselamatan dirinya sendiri.

d. Dalam kisah Yehuda dan Tamar (Ke. 38), dilukiskan mengenai ketidakberdayaan Yehuda terhadap Tamar. Bahkan dalam kisah selanjutnya diuntai pengetahuan mengenai garis keturunan Yesus Kristus yang salah satunya berasal dari Rahim Tamar.

e. Kisah-kisah seputar Musa, yaitu mengenai peranan putri Firaun, Ibu Musa (Yokhebet), dan Miryam yang jelas-jelas ditempatkan sebagai tokoh yang berjasa bahkan penting dalam kehidupan pribadi Musa.

Selain apa yang telah diungkap di atas, gambaran mengenai TUHAN secara anthropomorfis juga mau menjelaskan mengenai unsur kehalusan perasaan seseorang terhadap apa yang diyakininya sebagai Pelindung dan Penyelamat hidup manusia. TUHAN yang anthropomof adalah TUHAN yang memiliki kemesraan dan keintiman dengan manusia seperti halnya hubungan seorang mempelai laki-laki dengan perempuan; dan gambaran semacam ini umumnya dibiliki oleh seorang perempuan.

Dengan asumsi yang terhadir di atas, penulis setuju dengan pendapat Bloom yang menyatakan bahwa redaktur dari sumber $\mathrm{Y}$ adalah perempuan, sehingga kisah yang

\footnotetext{
8 Ibid., 9-16, 226.

${ }^{9}$ Ibid., 55-139
} 
digambarkan dalam Kej. 4: 24-26 merupakan hasil peredaksian perempuan yang memiliki kepedulian terhadap perempuan (dalam hal ini Zipora).

\section{Pembahasan}

\section{Tafsir Keluaran 4: 24-26}

\section{Siapa yang Hendak dibunuh TUHAN?}

Pertanyaan pertama yang penulis temui dalam bagian ini adalah: siapa sebenarnya yang hendak dibunuh oleh TUHAN? Pertanyaan ini muncul karena dalam bagian ini (Kel. 4:24-26) tidak pernah dijumpai bahwa objek yang hendak dibunuh oleh TUHAN adalah Musa. Meskipun dalam beberapa terjemahan nama Musa sudah ditemukan sejak ayat 24,10 namun dalam teks berbahasa Ibrani (Biblia Hebraica) tidak pernah ditemukan kata Musa secara eksplisit. Dengan tidak ditemukannya kata Musa, dalam naskah aslinya, maka perlu terlebih dahulu mengidentifikasi siapa sebenarnya orang yang hendak dibunuh oleh TUHAN. Akibatnya muncul spekulasi-spekulasi mengenai pribadi yang akan dibunuh TUHAN ini, antara lain:

i) King James Version (KJV) menekankan bahwa yang hendak dibunuh oleh TUHAN bukanlah Musa, melainkan salah seorang dari anak Musa. Penyebabnya adalah belum disunatnya anak-anak Musa sehingga TUHAN bermaksud membunuh salah seorang anak Musa yang dipandang bukan merupakan bagian dari Perjanjian Allah dengan Abraham (Kej. 17:14).11

ii) New International Version (NIV) secara implisit (karena hanya ditempatkan sebagai catatan kaki) mengatakan bahwa yang hendak dibunuh TUHAN adalah salah seorang dari anak Musa, bukan Musa. ${ }^{12}$

iii) Revised Standard Version (RSV) ${ }^{13}$ menambahkan kata Musa dalam ayat 25 untuk menegaskan tentang pribadi yang akan dibunuh TUHAN. Sedangkan Alkitab yang diterjemahkan ke dalam bahasa Indonesia (TB-LAI, BIS-LAI dan Alkitab terbitan Gandum Mas) justru sudah menambahkan nama Musa sejak ayat 24. Kemungkinan besar semua terjemahan ini memiliki maksud sama yang mau menjelaskan bahwa sasaran/obyek yang akan dibunuh oleh TUHAN adalah Musa.

iv) Beberapa pendapat ahli juga mengungkapkan bahwa yang hendak dibunuh TUHAN adalah Musa. ${ }^{14}$

10 Lih. TB LAI, Alkitab (Jakarta: Lembaga Alkitab Indonesia, 1992), 71; BIS-LAI, Alkitab (Jakarta: Lembaga Alkitab Indonesia, 1987), 81; LAI, Alkitab Penuntun Hidup Berkelimpahan (Malang: Gandum Mas, 1999), 101; New International Version, Holy Bible (Colorado Springs: International Bible Society, 1984), 43. Namun di sini perlu dicatat bahwa NIV memberi catatan kaki terhadap kata Moses, yang menjelaskan bahwa kemungkinan kata Moses di sini menunjuk pada Moses' son (anak Musa)

${ }^{11}$ Dake's Annoted Reference Bible, The Holy Bible (Georgia: Fisnish Jenning Dake, Dake Bible Sales Inc., 1979), 68

12 New International Version, Holy Bible, 43

13 George W. Coats, "Moses: Heroic Man, Man of God”, 70

${ }^{14}$ Beberapa pendapat para ahli tersebut dapat dilihat dalam: Terence E. Freitheim, Interpretation A Bible Commentery for Teaching and Preaching: Exodus (Louiseville, Kentucky: John Knox Press, 1991), 78; 
Menanggapi permasalah dan diskusi di atas, penulis lebih cenderung memilih pendapat yang mengatakan bahwa Musalah yang menjadi sasaran untuk dubunuh oleh TUHAN. Hal ini penulis hadirkan dengan beberapa alasan, antara lain:

a) Ketika TUHAN mengutus Musa untuk kembali ke Mesir meninggalkan Yitro (Kel. 4: 1-25), dikisahkan bahwa Musa membawa seluruh keluarganya (Zipora dan kedua anaknya, Gershom dan Eliezer) menuju Mesir untuk menjupai Firaun dan bangsa Israel. Dalam tradisi Israel, posisi/kedudukan seorang bapak/ayah adalah sentral, sebagai subyek dari keluarga. ${ }^{15}$ Dengan melihat kenyataan ini, di satu sisi, penulis berpendapat bahwa penggunaan kata ganti orang ketiga, tunggal dan maskulin, dalam ayat 24, mengarah pada diri Musa sebagai subyek dan kepala keluarga. Alangkah janggalnya jika penggunaan itu dikenakan kepada salah satu dari anak Musa. Di sisi lain, dengan jalan memperhatikan penulisan sebuah kata dengan penambahan akhiran (suffix) kata ganti orang ketiga, tunggal, maskulin, di mana kata itu muncul sesudah kalimat yang menerangkan peristiwa sebelumnya tentang 'seseorang' (dalam hal ini Musa) yang mendapat pengutusan, maka kata ganti orang ketiga, tunggal, maskulin itu cenderung menunjuk pada orang yang digambarkan serta dikabarkan sebelumnya, yaitu Musa.

b) Pendapat para ahli yang melihat peristiwa ini melalui kacamata 'tradisi Musa'16, yang menempatkan pokok 'ketaatan' sebagai pokok utama teologisnya; sehingga oknum yang hendak dibunuh oleh TUHAN jelas-jelas menunjuk pada Musa, yang saat itu dipandang tidak memiliki ketaatan mutlak kepada TUHAN dalam menjalankan tugas panggilan dan pengurtusannya, Hal ini tampak dalam kisah mengenai perbantahan yang dilakukan oleh Musa terhadap TUHAN yang mengutusnya, dan mengakibatkan TUHAN menjadi murka. ${ }^{17} \mathrm{Hal}$ inilah yang semakin menguatkan argumentasi penulis untuk mengatakan bahwa Musalah pribadi yang hendak dibunuh oleh TUHAN.

c) Apabila akhiran (suffix) dengan kata ganti orang ketiga, tunggal, maskulin menunjuk pada diri salah seorang dari anak Musa18, maka keberatannya terletak pada sosok yang pernah mengalami perjumpaan dengan TUHAN secara pribadi. Dalam kisah sebelumnya digambarkan bahwa Musa telah mengalami perjumpaan secara pribadi dengan TUHAN (Kel. 3: 4-22, kisah tentang peristiwa perjumpaan Musa dengan Tuhan melalui semak belukar yang terbakar dan Keluaran 4: 1-23, kisah tentang peristiwa pengulangan

pendapat Martin Buber yang diungkapkannya dalam David Rosenberg dan Harold Bloom, 206; Gerald Janzen, Exodus (Louiseville, Kentucky: John Knox Press, 1997), 44, dan HL Ellison, The Daily Study Bible Series: Exodus (Louiseville, Kentucky: John Knox Press, 1982), 27-28

${ }^{15}$ John L. Kenzie, A Theology of The Old Testament (USA: Geoffrey Chapman, 1974), 235-236.

${ }^{16}$ George W. Coats, "Moses: Heroic Man, Man of God", 66. Secara eksplisit Coats mengatakan, “... $a$ key item in Moses tradition is a theologoumenon about obedience..."

17 David Rosenberg dan Harold Bloom, The Book of J, 206. Bdk juga dengan Gerald Janzen, 44.

${ }^{18}$ Seperti yang ditulis, baik secara implisit maupun eksplisit, oleh NIV, Holy Bible, 43 dan juga Dake's Annotated Reference Bible, The Holy Bible, 68. 
pengutusan TUHAN kepada Musa, yang sekaligus menjadi latar belakang dekat dengan perikop yang menjadi sorotan dalam tulisan ini). Nyatalah di sini bahwa yang pernah mengalami perjumpaan dengan TUHAN adalah Musa, sehingga yang dimaksud dengan sosok yang akan dibunuh TUHAN dalam Keluaran 4: 24-26 benar-benar menunjuk pada pribadi Musa.

\section{Mengapa TUHAN hendak membunuh Musa?}

Pertanyaan di atas adalah pertanyaan yang sangat krusial. Karena jika ditilik dari peristiwa pengutusan TUHAN kepada Musa, maka ada harapan besar yang dinyatakan TUHAN terhadap Musa. Namun sekarang, mengapa TUHAN berniat untuk membunuh Musa? Bukankah hal ini janggal dan aneh; apalagi kalau secara logis dilihat bahwa TUHAN telah mempercayakan tugas kepada Musa, tapi kemudian sebelum tugas itu dilaksanakan TUHAN malahan berencana untuk membunuh Musa. Itu berarti bahwa TUHAN merencanakan untuk membunuh utusan-Nya sendiri.

Bila kembali pada teks, akan dijumpai kesan bahwa TUHAN sungguh-sungguh bermaksud membuhun Musa. Tindakan TUHAN bukan sekadar dating dan mengan-cam Musa, melainkan sungguh-sungguh 'diniati' untuk dating dan membunuh Musa. Dari bagian cerita ini, timbul pertanyaan: apa yang menjadi dasar dan sebab utama tindakan TUHAN dalam merencanakan untuk membunuh Musa? Apakah ada kemarahan yang tersimpan, kemarahan yang begitu besar, sehingga TUHAN sendiri melupakan pengutusan-Nya kepada Musa dan bahkan menggantikan perintah pengutusan itu dengan keinginan yang sungguh-sungguh untuk membunuh Musa?

Salah seorang penafsir, yaitu Freitheim ${ }^{19}$, berpendapat bahwa kemarahan TUHAN terjadi karena Musa saat itu belum disunat, dan hal ini sangat menyalahi Perjanjian TUHAN. Karena itu, nasib dan keselamatan Musa harus didapat melalui darah khatan anaknya. Keberatan terhadap pandangan ini justru ada dalam kitab Keluaran itu sendiri. Penulis berasumsi bahwa mustahil apabila Musa belum disunat pada saat itu; karena dalam peristiwa kelahiran Musa dikisahkan bahwa Musa hidup bersama orang tuanya selama tiga bulan, sebelum ia dihanyutkan ke sunai Nil (Kel. 2:2). Menurut tradisi bangsa Israel, bayi dengan usia delapan hari harus disunatkan sebagai tanda Perjanjian TUHAN sekaligus menunjuk pada nilai diri kebangsaannya sebagai bangsa Isral.20

Dan pada saat ia dihanyutkan ke sungai Nil kemudian diambil oleh putri Firaun, dikatakan dalam kisah itu bahwa putri Firaun langsung tahu bahwa Musa adalah bayi Israel/Ibrani (Kej. 2: 1-10). Petunjuk mana yang membuka pemahaman putri Firaun bahwa Musa adalah bayi Israel/Ibrani, kalau bukan keadaan Musa yang saat itu sudah disunat. Tentulah di usia tiga bulan Musa sudah disunatkan oleh orang tuanya (apalagi

\footnotetext{
19 Terrence E. Freitheim, Interpretation A Bible Commentery for Teaching and Preaching: Exodus, 7879

20 Yayasan Bina Jasih/OFM, Ensiklopedi Alkitab Masa Kini (Jakarta: Yayasan Komunikasi Bina Kasih/OFM, 1995), 426-427.
} 
kalau diingat bahwa orang tua mereka berasal dari suku Lewi, yaitu kelompok para imam yang teguh menjaga Perjanjian TUHAN). Dengan demikian pendapat Fretheim dapat dikatakan lemah dan sulit untuk diterima.

Pendapat lain mengatakan bahwa kemarahan TUHAN terjadi karena Musa belum sepenuhnya taat kepada TUHAN, padahal dalam Perjanjian TUHAN ketaatan merupakan syarat mutlak, karena TUHAN senantiasa menuntut ketaatan mutlak dari umat-Nya sebagai tindakan yang menjaga Perjanjian. ${ }^{21}$ Penulis memandang bahwa pendapat ini lebih bisa diterima; karena jika berbicara tentang panggilan Musa, maka peristiwa tersebut tidak dapat dipisahkan dari hukum tradisi Musa yang mengikuti segala peristiwa keluarnya bangsa Israel dari tanah Mesir. Hal ini bisa dilihat dari peristiwa pemberian Hukum Taurat dalam Keluaran 20, yang termasuk dalam hukum tradisi Musa, yang menggarisbawahi bahwa dalam menjaga Hukum Taurat yang diberikan TUHAN kepada Musa dan Israel dituntut ketaatan sebagai syarat utama yang mutlak harus dilakukan oleh bangsa Israel. Ketaatan mutlak adalah pedoman pokok kehidupan bangsa Israel selaku umat TUHAN. Ketaatan yang dikembangkan di sini bukan sekadar ketaatan dalam bidang rohani saja, melainkan juga meliputi semua yang bersifat jasmaniah (mislanya: sunat), karena unsur jasmaniah itu tidak pernah dapat dipisahkan dari unsur rohaniah. Setiap orang Israel dipanggil sebagai sekutu TUHAN dalam kaitannya selaku orang yang mengikuti peraturan Perjanjian seperti yang telah ditetapkan TUHAN kepada Abraham (Kej. 17). ${ }^{22}$

Jika ditelusuri lebih jauh lagi alur cerita dalam Keluaran 4: 24-26, agaknya Musa lupa terhadap unsur penting dalam Perjanjian TUHAN ini. Musa lupa untuk menyunatkan anaknya (kedua anaknya), karena Musa telah hidup di luar bangsa Israel sedemikian lamanya, khususnya pada saat Musa menjalani masa pelariannya. Kealpaan Musa inilah yang mengundang kemarahan TUHAN. Hal ini terjadi karena dalam pelariannya, Musa telah berjumpa dan sekaligus mengawini Zipora, seorang perempuan Midian, dan bangsa Midian sendiri tidak pernah mengenal sunat sebagai kewajiban untuk dilakukan. ${ }^{23}$ Dengan demikian dapat dipahami ketika Musa melakukan perjalanan bersama keluarganya menuju Mesir dalam rangka memenuhi pengutusan TUHAN kepadanya, kedua anak Musa belum disunat. Hal inilah yang membuat kemarahan TUHAN begitu memuncak, karena jika dilihat dengan kejernihan berpikir maka akan dijumpai peristiwa ironis yang begitu dalam. Musa yang diutus oleh TUHAN menjadi pembebas bangsa Israel, justru adalah orang pertama yang tidak memenuhi kewajiban dalam ikatan Perjanjian TUHAN. Jika ini diteruskan, maka akan terjadi halhal yang sungguh memalukan dan tidak bisa dipertanggungjawabkan.

Kemarahan TUHAN kepada Musa agaknya lebih 'ekstra' lagi apabila dibandingkan dengan kemarahan TUHAN kepada yang lain. Hal ini dapat dimengerti, karena dalam

${ }^{21}$ Martin Buber dalam Gerald Janzen, 44, band: David Rosenber dan Harold Bloom, The Book of J, 206.

22 George W. Coats, “Moses: Heroic Man, Man of God”, 66-67.

23 Yayasan Bina Jasih/OFM, Ensiklopedi Alkitab Masa Kini , 426-427. 
kasus ini TUHAN telah menetapkan Musa sebagai utusan-Nya yang harus menyampaikan kebenaran dan ketaatan kepada TUHAN; padahal Musa sendiri belum memiliki ketaatan yang mutlak kepada TUHAN.

Jika semua argument di atas dapat diterima, maka pertanyaan lain yang muncul adalah: mengapa kemarahan TUHAN harus diungkapkan melalui keinginan-Nya membunuh Musa? Apakah hal ini tidak berlebihan? Menanggapi pertanyaan ini, beberapa penafsir merasa bingung. ${ }^{24}$ Berbeda dengan beberapa penafsir, teks ini dipandang sebagai sebuah penjelasan mengenai misteri TUHAN dalam menanggapi keberadaan manusia yang adalah ciptaan-Nya. Di sini penulis mau menekankan bahwa banyak hal yang tidak dapat dipahami oleh manusia untuk mengerti tindakan TUHAN, karena eksistensi TUHAN jauh lebih besar dari jangkauan pikiran manusia.

Apabila ada anggapan yang mengatakan bahwa kisah ini adalah gambaran mengenai inkonsisensi TUHAN dalam sejarah keselamatan bangsa Israel dan Musa, bagi penulis hal ini perlu untuk direnungkan terlebih dahulu. Karena, seperti yang sudah penulis ungkapkan di atas, perlu bagi manusia untuk mengakui bahwa ada banyak bagian dalam jalan pikiran TUHAN yang sulit untuk dipahami dan diselami. karena itu, penulis akan mencoba menghentikan sejenak bagian ini dan penulis akan mengalihkan ke bagian lain yang akan membuka sebuah wawasan lain mengenai cara kerja TUHAN dalam mengelola pikiran manusia. Dari bagian lain ini, nantinya, penulis akan memperlihatkan apakah memang benar TUHAN itu inkonsiten terhadap janji dan pengutusan-Nya atau justru tetap konsisteni.

\section{Sebuah Tindakan Penyelamatan}

Dalam kisah ini, sebenarnya yang menjadi tokoh utama/sentral dalah Zipora, karena dialah satu-satunya orang yang 'mengetahui' rencana TUHAN untuk membunuh Musa, suaminya. Memang sedikit aneh apabila dikatakan bahwa tokoh sentral dalam kisah ini adalah Zipora, bukan Musa, karena Zipora 'hanyalah' seorang perempuan. Bukan sekadar seorang perempuan, bahkan Zipora adalah seorang perempuan non-Yahudi. Ini sungguh aneh dan di luar kebiasaan dalam penulisan kitab-kitab yang bercirikan sastra Yahudi. Namun di sinilah uniknya sumber/redaktur Y, yang dengan sengaja dan dengan tujuan tertentu menempatkan Zipora sebagai tokoh penyelamat Musa dengan jalan membuat "Darah Perjanjian' melalui kulit khatan anaknya.

Agak sulit untuk mengartikan makna dari idiom 'Pengantin Darah', seperti yang ditulis dalam ayat 25 dan 26. Tetapi penulis melihat bahwa hal ini berkaitan erat dengan tradisi bangsa Israel yang dipandang sebagai 'mempelai TUHAN', di mana dengan sebutan itu bangsa Israel dipandang sebagai bangsa yang terhisab dalam persekutuan dengan TUHAN. Hal lain yang tidak kalah pentingnya jika mengamati istilah 'pengantin darah' yaitu mengenai kata 'darah' itu sendiri. Dalam pemahaman

24 Terrence E. Freitheim, Interpretation A Bible Commentery for Teaching and Preaching: Exodus, 8081 dan George W. Coats, "Moses: Heroic Man, Man of God", 70. 
bangsa Israel, darah seringkali merujuk pada pemaknaan mengenai kultus kurban, di mana darah dipandang sebagai bentuk kehidupan yang sudah dibebaskan dari segala keterbatasan tubuh dan dimerdekakan untuk tujuan-tujuan lain, karena darah dipandang sebagai tempat jiwa terletak. ${ }^{25}$ Dengan demikian istilah 'Pengantin Darah' yang diberikan Zipora kepada Musa menunjukkan bahwa Musa telah diikat kembali dalam persekutuannya dengan TUHAN, sekaligus diangkat untuk memasuki kemerdekaan kekal bersama TUHAN.

Dalam melakukan tindakan penyelamatan terhadap Musa, Zipora telah melakukan sebuah upacara yang tidak lazim, di mana Zipora sendiri yang menyu-natkan anaknya (hal ini berarti Zipora telah membuat Perjanjian dengan TUHAN, Allah bangsa Israel) dan kemudian menempelkan kulit khatan anaknya ke antara kedua kaki Musa ('kemaluan' Musa). Agaknya ini merupakan tindakan simbolis dari Zipora untuk menyelamatkan Musa. Dengan menyunat anaknya, Zipora telah membuat Perjanjian damai dan keselamatan dengan TUHAN. Dan ketika Zipora menempelkan tanda Perjanjian itu ke 'kemaluan' Musa, maka Zipora telah mema-teraikan keselamatan itu dalam diri Musa. Ini merupakan tanda bahwa sejak saat itu Musa telah dikembalikan lagi pada hakikatnya sebagai umat yang ada dalam kesatuan bangsa Israel dengan TUHAN. Semua ini dilakukan Zipora sebagai tanda cinta terhadap Musa dan tanda cinta inilah yang kemudian menyelamatkan Musa dari kematian. Ayat selanjutnya jelas, dikatakan bahwa TUHAN pun melepaskan Musa dari rencana pembunuhan-Nya.

Menilik dari kisah yang 'agak asing' di atas, agaknya ada satu pesan penting yang hendak disampaikan redaktur kepada para pembaca Alkitab. Redaktur sangat menekankan peranana seorang perempuan sebagai seorang pendamping, yang berada dalam posisi sebagai 'penolong' bagi laki-laki, Hal ini berarti hendak merombak padangan patriarkhi yang begitu dominan dalam kisah Keluaran. Seorang perempuan (entah itu yang terhisab dalam bangsa pilihan atau bukan, dalam hal ini diwakili oleh Zipora) 'memiliki hak mutlak' untuk membuat Perjanjian damai dan/atau keselamatan dengan TUHAN. Bahkan dalam membangun Perjanjian tersebut, seorang perempuan dapat mengangkat seorang laki-laki sebagai bagian dari Perjanjian tersebut.

Pesan ini sungguh luar biasa, karena dengan menempatkan pesan tersebut dalam kisah Keluaran ini, para pembaca diajak masuk ke dalam dunia pikiran yang lain, di mana TUHAN menempatkan perempuan sebagai 'sahabat/mitra' TUHAN dan memiliki hak untuk membuat Perjanjian hidup dengan TUHAN, bahkan Perjanjian tersebut meliputi seluruh keluarganya. Bukankah hal ini menjadi sebuah berita baru yang mencelikkan mata setiap pembaca, bahwa seorang perempuan memiliki hak yang sangat istimewa di hadapan TUHAN?

Tindakan penyelamatan Zipora ini menjadi titik penolong utama dalam kisah sejarah kehidupan Musa, karena sejak awal Musa selalu mendapat pertolongan dari para perempuan yang ada di sekitarnya (putri Firaun, Miryam (kakaknya), dan ibunya).

${ }^{25}$ Yayasan Bina Jasih/OFM, Ensiklopedi Alkitab Masa Kini, 236. 
Kisah ini bukan tanpa maksud ditempatkan secara sengaja oleh redaktur, karena melalui kisah ini para pembaca disadarkan kembali betapa pentingnya peran seorang perempuan dalam kehidupan Musa, sehingga Musa dapat tampil menjadi seorang pahlawan bagi TUHAN dan bagi bangsa Israel. Semua karena peran perempuan. Dengan kata lain, keberhasilan Musa adalah hasil didikan, topangan dan upaya penyelamatan yang dilakukan oleh para perempuan yang hadir di sekitar hidupnya.

Kisah ini berakhir dengan happy ending story. Musa diselamatkan oleh Zipora, melalui Perjanjian yang dibuat oleh Zipora dengan TUHAN. Musa dikembalikan kekudusannya oleh TUHAN, karena Zipora. Ketidaktaatan Musa telah ditutupi oleh ketaatan Zipora. Perubahan rencana TUHAN, yaitu hendak membunuh Musa, telah diluruskan kembali oleh ZIpora melalui ketaatannya. Hal ini merupakan gambaran yang sangat baik untuk menampilkan aspek kekuatan yang menyelamatkan dalam diri seorang perempuan.

\section{Refleksi}

Dari kisah di atas, maka dapat diambil beberapa pemahaman, yakni:

Pertama, jika dalam kisah ini didapatkan kesan bahwa TUHAN inkonsisten terhadap pengutusannya kepada Musa, maka sesungguhnya pendapat itu sangat tidak tepat. Karena yang dibutuhkan TUHAN adalah ketaatan, dan Musa telah menunjukkan ketidaktaatannya. Inilah yang menyebabkan TUHAN berniat hendak membatalkan semua yang telah dirancang-Nya terhadap Musa. Dalam menjalankan misi pengutusan, dibutuhkan ketaatan yang menunjukkan pada kekudusan hidup. Jika Musa tidak bisa menunjukkan kekudusan hidupnya, bagaimana Musa dapat meyakinkan bangsa Israel untuk hidup kudus dan taat di hadapan TUHAN?

Namun ketidaktaatan Musa ini kemudian ditutupi oleh ketaatan Zipora. Hal ini mau menunjukkan bahwa segala kesalahan yang dilakukan oleh Musa (dan manusia pada umumnya) akan mendapat pengampunan apabila ada 'mediator' yang bersedia untuk mengembalikan kekudusan dan ketaatan Musa (dan manusia pada umumnya). Di sinilah Zipora mengambil peran yang sangat penting. Zipora tampil sebagai 'mediator', sehingga Musa mengalami pertobatan dan hal ini mendapat respons positif dari TUHAN.

Itulah yang terjadi dengan manusia sekarang. Manusia sekarang tidak akan pernah bisa mendapatkan keselamatan dari TUHAN jika mengandalkan dirinya sendiri, karena manusia sekarang telah jatuh ke dalam dosa dan hidup dalam ketidakkudusan. Namun karena ada Yesus, sebagai 'Mediator', maka manusia pun akan diijinkan untuk memasuki masa-masa persekutuan yang indah kembali bersama TUHAN.

Kedua, dalam kehidupan di Indonesia, agaknya manusia Indonesia harus sadar bahwa situasi yang sedang dialami kahir-akhir ini harus dipandang sebagai situasi yang tercipta melalui tindakan aktif TUHAN terhadap kehidupan berbangsa dan bermasyarakat di Indonesia. Segala kemalangan, penderitaan, peperangan, konflik, kerusuhan etnis dan setiap bentuk pergumulan dan penderitaan lainnya merupakan konsekuensi logis dari tindakan TUHAN yang agaknya perlu untuk diselami secara 
mendalam oleh bangsa Indonesia ini. Atau mungkin juga sebagai dorongan bagi bangsa Indonesia untuk kembali meletakkan pengharapan kepada TUHAN, agar TUHAN mau mengampuni bangsa Indonesia yang seringkali melupakan jati dirinya sebagai bangsa yang Bertuhan.

Mungkin saja saat ini TUHAN sedang kecewa karena bangsa Indonesia telah lalai untuk hidup kudus di hadapan-Nya; sehingga TUHAN berencana untuk membenturkan bangsa Indonesia dengan segala bentuk penderitaan seperti yang terjadi sekarang (misal: bencana alam). Untuk itu, bangsa Indonesia harus berani untuk belajar merendahkan hati kembali pada TUHAN dan membangun kembali Perjanjian Kehidupan dengan TUHAN melalui cara-cara hidup yang terhormat dan bermartabat.

Ketiga, menanggapi 'kekecewaan' TUHAN yang begitu dalam, adalah lebih bijaksana jika bangsa Indonesia mulai menyadari segala perbuatannya yang telah mematahkan perjanjian dengan TUHAN. Harus ada rekonsiliasi nasional, di mana masing-masing individu harus mengadakan pendamaian dengan sesamanya, sekaligus hal ini menunjukkan bahwa ia sedang mengupayakan pendamaian dengan TUHAN. Di samping itu, sudah saatnya bangsa Indonesia melakukan pertobatan massl dan kembali membangun kehidupan beragamanya dengan didasarkan atas pemahaman yang lebih baik mengenai keberadaan TUHAN dalam setiap aspek kehidupan. Bangsa Indonesia harus memahami bahwa tidak selamanya TUHAN diam dalam menyaksikan segala bentuk ketidakadilan. Ada saatnya TUHAN akan bertindak secara nyata, dan tidakan ini bisa saja begitu menakutkan dan menggentarkan.

\section{Kesimpulan}

Kisah dalam Keluaran 4:24-26 ini hendak menegaskan kembali aspek kesetaraan antara laki-laki dan perempuan. Para pembaca diharapkan memiliki pemahaman bahwa perempuan pun memiliki hak untuk masuk, membuat dan menjaga Perjanjian dengan TUHAN (jadi Perjanjian itu bukan milik pribadi laki-laki). Perempuan dapat membangun Perjanjian keselamatan dan/atau damai dengan TUHAN, karena perempuan adalah rekan/mitra TUHAN dalam setiap aspek kehidupan. Kisah ini juga hendak mengajak laki-laki untuk 'bertobat' ketika mereka memandang dirinya lebih superior dibandingkan perempuan. Keberadaan dan kejayaan seorang pejuang laki-laki tidak pernah terlepas dari keberadaan seorang perempuan yang ada di sampingnya. Bahkan kisah ini menegaskan bahwa keberadaan perempuan adalah titik sentral bagi kehidupan laki-laki. Bagi kehidupan masa kini dan di Indonesia, kisah ini mau mengajak setiap bagian dari bangsa ini untuk menata kembali hubungan yang tidak harmonis antara laki-laki dan perempuan. Harus ada kesetaraan yang jelas antara laki-laki dan perempuan di dalam setiap aspek kehidupan yang dijalani bersama. Kesetaraan ini jangan hanya ada dalam tataran akademis dan wacana-wacana ilmiah saja, melainkan harus bisa mengejawantah dalam kehidupan nyata sehari-hari.

\section{Referensi}


Bahasa Indonesia Sehari-hari - Lembaga Alkitab Indonesia, Alkitab. Jakarta: Lembaga Alkitab Indonesia, 1987.

Bloomendal, J., Pengantar Kepada Perjanjian Lama. Jakarta: BPK Gunung Mulia, 1983.

Carwoto, "Mengungkap dan Mengeliminasi Kekerasan Terhadap Istri" dalam Rifka Annisa, Menggugat Harmoni. Yogyakarta: Rifka Annisa Women's Crisis Center, 2000.

Coats, George W., "Moses: Heroic Man, Man of God", dalam Journal for The Study of The Old Testament Suplement, Series 57. Sheffield: JSOT Press, 1988.

Dake's Annoted Reference Bible, The Holy Bible. Georgia: Fisnish Jenning Dake, Dake Bible Sales Inc., 1979

Davidson, Robert (alih bahas: E.G. SInggih), Alitab Berbicara. Jakarta: BPK Gunung Mulia, 1986.

Ellison, H.L., The Daily Study Bible Series: Exodus. Louiseville, Kentucky: John Knox Press, 1982.

Freitheim, Terence E., Interpretation A Bible Commentery for Teaching and Preaching: Exodus. Louiseville, Kentucky: John Knox Press, 1991.

Janzen, Gerald, Exodus. Louiseville, Kentucky: John Knox Press, 1997.

Kenzie, John L., A Theology of The Old Testament. USA: Geoffrey Chapman, 1974

Lembaga Alkitab Indonesia, Alkitab Penuntun Hidup Berkelimpahan. Malang: Gandum Mas, 1999

New International Version, Holy Bible. Colorado Springs: International Bible Society, 1984

Rifka Annisa, Di Balik Tirai Tabu. Yogyakarta: Rifka Annisa Women’s Crisis Center, 2000

Rosenberg, David dan Harold Bloom, The Book of J. New York: Faber \& Faber, Grove Weidenfeld, 1990

Soetrisno, Loekman, Kemiskinan, Perempuan, dan Pemberdayaan. Yogyakarta: Kanisius, 1997

Terjemahan Baru - Lembaga Aalkitab Indonesia, Alkitab. Jakarta: Lembaga Alkitab Indonesia, 1992

Yayasan Bina Jasih/OFM, Ensiklopedi Alkitab Masa Kini. Jakarta: Yayasan Komunikasi Bina Kasih/OFM, 1995 